\title{
Ampicillin plus probenecid compared with procaine penicillin plus probenecid in the treatment of gonorrhoea
}

\author{
P. K. TAYLOR AND A. D. SETH \\ From the Department of Venereal Diseases and the Venereal Diseases Reference Laboratory, The London \\ Hospital
}

Ampicillin has been used in the treatment of gonorrhoea since Ödegaard (1962) reported it to have a greater bactericidal effect than penicillin $G$ in vitro against less sensitive strains of gonococci. Good results in treating patients failing to respond to benzyl penicillin were reported by Willcox (1964a). Alergant (1963) reported a 5 per cent. failure rate in men using $1 \mathrm{~g}$. ampicillin in a single dose, but Willcox (1964b), using doses of up to $1 \mathrm{~g}$., found it to be less effective than $1 \cdot 2$ m.u. procaine penicillin by injection. His results were not improved by increasing the dose to $2 \mathrm{~g}$. Also using $2 \mathrm{~g}$. ampicillin, the failure rate of Eriksson (1970) was 8.8 per cent. and that of Bro-Jørgensen and Jensen (1971) 6.5 per cent.

Better results were obtained with $1 \mathrm{~g}$. ampicillin followed in $5 \mathrm{hrs}$ by a further $1 \mathrm{~g}$. (Willcox, 1965; Groth and Hallqvist, 1970; Eriksson, 1970). Using the same doses but with an interval of $24 \mathrm{hrs}$ between them, Jersild and Svendsen (1973) reported a 1.8 per cent. failure rate in a prison population.

Reports of enhanced blood levels by using probenecid together with the ampicillin (Robinson, 1964; Kvale, Keys, Johnson, and Holmes, 1971) favoured a return to the single-dose schedule. Eriksson (1971b) reported that the serum concentration of ampicillin after a dose of $2 \mathrm{~g}$. was doubled when it was used in conjunction with $1 \mathrm{~g}$. probenecid. In the Far East, Kvale and others (1971) reduced the failure rate from 29.3 per cent. to 4 per cent. by the addition of $2.5 \mathrm{~g}$. probenecid to their $3.5 \mathrm{~g}$. dose of ampicillin. Using $2 \mathrm{~g}$. ampicillin with $1 \mathrm{~g}$. probenecid, good results were obtained by Gundersen, Ödegaard, and Gjessing (1969)-1.4 per cent. failures, Keys, Halverson, and Clarke (1969)-1 per cent. failures, Eriksson (1971a) - 0.9 per cent. failures, Bro-Jørgensen and Jensen (1971)-1.9 per cent. failures, and Cobbold, Rees, Parker, Woodcock, John, Latto, Redmond, and Willcox (1973)-2.2 per cent. failures.

Received for publication October 28,1974

Address: P. K. Taylor, Whitechapel Clinic, The London Hospital, Turner Street, London E1 IBB
However, in London, Willcox, Woodcock, Latto, John, Redmond, Parker, Rees, and Cobbold (1973) had a 6.4 per cent. failure rate with the same dose.

The present trial was undertaken to see if the dose of $2.4 \mathrm{~m}$.u. procaine penicillin plus $2 \mathrm{~g}$. probenecid, which had been the routine treatment at The London Hospital for $2 \frac{1}{2}$ years, could be adequately replaced with a single oral dose of ampicillin and probenecid.

\section{Material and methods}

396 men suffering from acute gonoccal urethritis diagnosed by Gram-stained urethral smears were allocated in random fashion to one of three single-dose treatment schedules. Those patients who were allergic to penicillin or were habitual defaulters or unable to attend for regular follow-up were excluded. Initial cultures were positive in approximately 92 per cent. of the patients. Isolates were confirmed as $N$. gonorrhoeae by fermentation tests.

TREATMENT SCHEDULES

(1) 2.4 m.u. procaine penicillin intramuscularly together with $2 \mathrm{~g}$. probenecid orally.

(2) $2 \mathrm{~g}$. ampicillin orally together with $2 \mathrm{~g}$. probenecid orally.

(3) $3 \mathrm{~g}$. ampicillin orally together with $2 \mathrm{~g}$. probenecid orally.

\section{AGE AND NATIONALITY}

The average age and age range in the three treatment groups was similar, as was the distribution of the various nationalities (Table I).

FOLLOW-UP TESTS

Follow-up smears and cultures of the urethral material were taken on or about the 3rd, 7th, 14th, 21st, and 28th day after treatment. At each visit smears and cultures were taken whether there was obvious discharge or not. Postgonococcal urethritis was diagnosed from the 7th day onwards if the pus count per high-power field was over 30 . These patients were treated with oxytetracycline $500 \mathrm{mg}$. four times a day for 1 to 2 weeks.

\section{DEFAULT RATE}

Of the 396 patients originally treated in the trial, 336 attended at least once after treatment (Table II), and 259 attended on 2 or more occasions after treatment. The 
TABLE I Age and nationality of patients in each treatment group

\begin{tabular}{|c|c|c|c|c|c|c|}
\hline \multirow[t]{2}{*}{ Treatment group } & \multicolumn{2}{|l|}{ Age (yrs) } & \multicolumn{4}{|l|}{ Nationality } \\
\hline & Average & Range & U.K. and Eire & Caribbean & Others & Total \\
\hline $\begin{array}{l}\text { (1) Procaine } \\
\text { penicillin } \\
+ \text { probenecid }\end{array}$ & $28 \cdot 2$ & $17-59$ & 48 & 52 & 32 & 132 \\
\hline $\begin{array}{l}\text { (2) 2g. ampicillin } \\
+ \text { probenecid }\end{array}$ & $28 \cdot 1$ & $16-61$ & 49 & 48 & 35 & 132 \\
\hline
\end{tabular}

TABLE II Patients followed and default rate

\begin{tabular}{|c|c|c|c|c|c|c|}
\hline \multirow[t]{2}{*}{ Treatment group } & \multirow[t]{2}{*}{ Total patients } & \multirow[t]{2}{*}{ Total followed } & \multicolumn{2}{|c|}{ Defaulters } & \multicolumn{2}{|c|}{$\begin{array}{l}\text { Defaulters before sending out } \\
\text { reminders }\end{array}$} \\
\hline & & & No. & Rate per cent. & No. & Per cent. \\
\hline $\begin{array}{l}\text { (2) 2g. ampicillin } \\
+ \text { probenecid }\end{array}$ & 132 & 112 & 20 & $15 \cdot 2$ & 39 & $29 \cdot 5$ \\
\hline $\begin{array}{l}\text { (3) 3g. ampicillin } \\
\text { + probenecid }\end{array}$ & 132 & 115 & 17 & $12 \cdot 9$ & 37 & $28 \cdot 0$ \\
\hline Total & 396 & 336 & 60 & $15 \cdot 2$ & 110 & $27 \cdot 8$ \\
\hline
\end{tabular}

default rate was significantly improved by the routine sending of letters to defaulters if they did not return 3 days after the initial visit. The number of defaulters at 3 days, before sending letters, was 110 (27.8 per cent.). After letters had been sent out a further fifty patients re-attended, thus reducing the overall default rate to 15.2 per cent. These figures are comparable to those found in Newcastle between January and June, 1970, by Wigfield, Selkon, and Rich (1973).

\section{SENSITIVITY TESTS}

Ampicillin and penicillin sensitivities were determined by an agar plate dilution method and the minimum inhibitory concentrations (MICs) reported. Brain heart infusion agar (Oxoid) containing 10 per cent. defibrinated horse blood (Oxoid) was used for sensitivity testing. Ampicillin was incorporated in the following concentrations: 0.008 , $0.015,0.03,0.06,0.125,0.25,0.5$, and $1.0 \mu \mathrm{g}$. per ml. The penicillin $G$ concentrations used were $0.06,0.125$, 0.25 , and $0.5 \mu \mathrm{g}$. per $\mathrm{ml}$. The inoculum for ampicillin (penicillin) sensitivity tests consisted of a loopful of suspension of gonococci from a 24-hr-old plate subculture suspended in nutrient broth to give a turbidity approximately equal to a 1 in 3 dilution of a MacFarland barium sulphate standard 1.5. The inoculated plates were incubated at $36^{\circ} \mathrm{C}$. in a candle-extinction jar for $48 \mathrm{hrs}$ before readings were taken.

Sensitivity tests to cotrimoxazole and tetracycline were made by a disc diffusion method derived from that of Stokes (1968). Discs containing 23.75 $\mu$ g. sulphamethoxazole and $1.25 \mu \mathrm{g}$. trimethoprim (SXT 25, Oxoid) and tetracycline (tetracycline 15, low potency, Evans Medical) were used. The medium used was the same as that for ampicillin (penicillin) sensitivity testing except that a mixture of 5 per cent. lysed blood (Wellcome) and 5 per cent. defibrinated horse blood (Oxoid) was used. For the disc diffusion method the gonococcal suspension mentioned above was diluted 1 in 2 and inoculated with a swab. For the disc sensitivity tests the Oxford Staphylococcus (NCTC 6571) was used as the reference organism. The inoculated plates were again incubated at $36^{\circ} \mathrm{C}$. in a candle-extinction jar for $48 \mathrm{hrs}$ before readings were taken. Results were reported as sensitive, moderately sensitive, or resistant according to the criteria of Stokes and Waterworth (1972).

\section{Results}

Table III shows the frequency of recurrences in the three treatment groups. All recurrences within 2 weeks of treatment were classed as possible treatment failures.

\section{PENICILLIN}

In Group 1 (procaine penicillin $2.4 \mathrm{~m}$.u. plus probenecid $2 \mathrm{~g}$.) there were three recurrences in the first week and none in the second, giving an overall failure rate in this period of 2.8 per cent. of the 109 patients followed. Two of these had positive smears and cultures and one had a negative smear and positive culture. One of the patients found to have positive tests 7 days after treatment admitted further sexual intercourse with the untreated original contact. The organism was sensitive to $0.06 \mu \mathrm{g}$. penicillin per $\mathrm{ml}$. Thus one of these three recurrences could well have been a re-infection. 
TABLE III Results of treatment

\begin{tabular}{|c|c|c|c|c|c|c|c|c|}
\hline \multirow{2}{*}{ Treatment group } & \multirow{2}{*}{ No. treated } & \multirow{2}{*}{ No. followed } & \multicolumn{6}{|c|}{ Recurrences } \\
\hline & & & No. & Per cent..$^{\mathrm{a}}$ & No. & Per cent. ${ }^{\mathrm{a}}$ & No. & Per cent. ${ }^{\mathrm{a}}$ \\
\hline $\begin{array}{l}\text { (1) Procaine } \\
\text { penicillin } \\
+ \text { probenecid }\end{array}$ & 132 & 109 & 3 & $2 \cdot 8$ & - & - & 3 & $2 \cdot 8$ \\
\hline $\begin{array}{l}\text { (3) 3g. ampicillin } \\
+ \text { probenecid }\end{array}$ & 132 & 115 & 1 & 0.8 & 5 & $4 \cdot 4$ & 6 & $5 \cdot 2$ \\
\hline
\end{tabular}

$\mathrm{a}=$ percentage of those followed

\section{AMPICILLIN}

In Group 2 (ampicillin 2 g. plus probenecid 2 g.) there were four recurrences in the first week and three in the second, two of whom had negative tests 3 days after treatment, giving an overall failure rate in this period of 6.2 per cent. of the 112 patients followed. Five of these had positive smears and cultures, one had a negative smear and positive culture, and one had a positive smear and negative culture. Two of the patients with recurrences in the first week and one in the second week admitted further sexual intercourse with the untreated original contact, so that these three recurrences may well have been due to re-infection; two of these patients had organisms sensitive to $0.06 \mu \mathrm{g}$. penicillin per $\mathrm{ml}$.

In Group 3 (ampicillin $3 \mathrm{~g}$. plus probenecid 2 g.) there was one recurrence in the first week and five in the second, giving an overall failure rate in this period of $5 \cdot 2$ per cent. of the 115 patients followed. Five of these had positive smears and cultures and one had a negative smear and positive culture. Three of the patients with recurrences in the second week admitted further sexual intercourse with the untreated original contact, two of them having had negative tests 3 days after treatment. All had organisms sensitive to $0.06 \mu \mathrm{g}$. penicillin per ml. Thus three of the recurrences in this group could well have been re-infections.

The penicillin and ampicillin sensitivities of the strains of gonococci for those patients who subsequently had recurrences are shown in Table IV.

\section{SIDE-EFFECTS}

One patient developed a rash after ampicillin but no other side-effects were observed.

POST-GONOCOCCAL URETHRITIS (PGU)

235 of the 336 patients followed were assessed for PGU. Those not assessed were patients who did not return after their first follow-up visit and patients classed as treatment failures. The results are shown

TABLE IV Pencillina sensitivities of gonococci in patients with recurrences

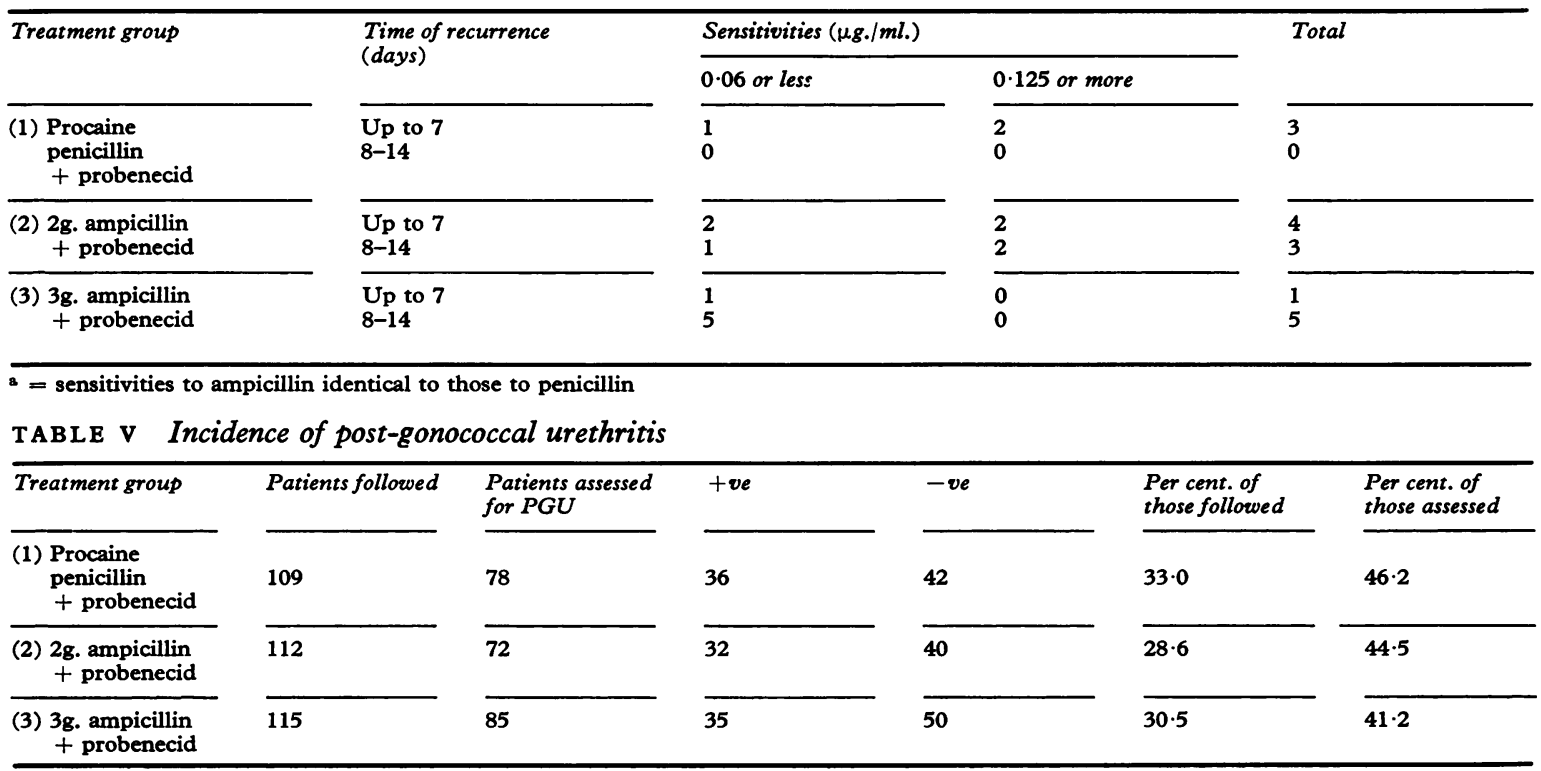


in Table V. There was no significant difference in the incidence of PGU in the three treatment groups. Roy and Laird (1974) reported a smaller incidence in a group treated with ampicillin than in a comparable group treated with penicillin.

It is difficult to compare the incidence of PGU with other series as in most reports the criteria for diagnosis of PGU are not stated. Symptoms and signs are often minimal and the thoroughness of follow-up examination will also affect the findings.

RESULTS OF SENSITIVITY TESTS

Sensitivity tests were carried out on strains of gonococci from 277 patients divided approximately equally between the three treatment groups. There was found to be very close correlation between the MICs of ampicillin and penicillin (Tables VI and VII). The results for 91 strains in which the MIC of either ampicillin or penicillin was $0.125 \mu \mathrm{g} . / \mathrm{ml}$. or more are shown in Table VIII.

TABLE VIII Comparison of MICs of ampicillin and penicillin for 91 strains of $\mathrm{N}$. gonorrhoeae when either one of the MICs is $0.125 \mu \mathrm{g} . / \mathrm{ml}$. or more

\begin{tabular}{|c|c|}
\hline Result & No. of cases \\
\hline Ampicillin and penicillin MICs are the same & 48 \\
\hline $\begin{array}{l}\text { Ampicillin MICs are lower than those of penicillin } \\
\text { by one dilution }\end{array}$ & 27 \\
\hline $\begin{array}{l}\text { Penicillin MICs are lower than those of ampicillin } \\
\text { by one dilution }\end{array}$ & 15 \\
\hline $\begin{array}{l}\text { Ampicillin MIC is less than that of penicillin by } \\
\text { two-fold dilution }\end{array}$ & 1 \\
\hline
\end{tabular}

Results of sensitivity testing to cotrimoxazole and tetracycline are shown in Table IX. Of the 277 strains isolated before treatment, 83 ( 30 per cent.) were sensitive to $0.125 \mu \mathrm{g} . / \mathrm{ml}$. or more of penicillin. Of these less sensitive strains, 44 (53 per cent.) were classed as resistant or moderately sensitive to cotrimoxazole compared with 33 (17 per cent.) of the 194 strains sensitive to $0.06 \mu \mathrm{g} . / \mathrm{ml}$. or less of penicillin. This difference is significant at the level of $P<0.01$. Compared with the figures of Rodin and Seth (1972), there is evidence of an increase in cross-resistance between penicillin and cotrimoxazole.

All 277 strains were found to be sensitive to tetracycline by the disc technique which was used.

\section{Discussion}

Oral ampicillin is well absorbed by mouth and has several advantages over intramuscular penicillin in the treatment of gonorrhoea. The work load of the clinic is eased by eliminating the use of syringes. Oral drugs are also more acceptable to most patients than injections and there is less risk of anaphylactic reactions.

There was no statistically significant difference in the failure rates in the three treatment groups. The figures for ampicillin are comparable to the failure rate of 6.4 per cent., also in London, reported by Willcox and others (1973) using $2 \mathrm{~g}$. ampicillin and 1 g. probenecid.

The number of strains of $N$. gonorrhoeae sensitive to $0.125 \mu \mathrm{g} . / \mathrm{ml}$. or more of penicillin at The London Hospital in 1968-69 was 19.9 per cent. (164 of 825

TABLE VI Sensitivity to ampicillin $f 277$ strains of $\mathrm{N}$. gonorrhoeae in vitro

\begin{tabular}{|c|c|c|c|c|c|c|c|c|}
\hline \multirow[t]{2}{*}{ Sensitivity } & \multicolumn{8}{|c|}{ Minimum inhibitory concentration $(\mu \mathrm{g} . / \mathrm{ml})}$. \\
\hline & $\leqslant 0.008$ & 0.015 & 0.03 & 0.06 & $0 \cdot 125$ & $0 \cdot 25$ & 0.5 & 1.0 \\
\hline No. & 52 & 73 & 37 & 30 & 55 & 27 & 3 & 0 \\
\hline Per cent. & $18 \cdot 8$ & $26 \cdot 3$ & $13 \cdot 4$ & $10 \cdot 8$ & 19.9 & $9 \cdot 7$ & $1 \cdot 1$ & 0 \\
\hline
\end{tabular}

TABLE VII Sensitivity to penicillin of 277 strains of N. gonorrhoeae in vitro

\begin{tabular}{|c|c|c|c|c|c|c|c|c|}
\hline \multirow[t]{2}{*}{ Sensitivity } & \multicolumn{8}{|c|}{ Minimum inhibitory concentration $(\mu \mathrm{g} . / \mathrm{ml})}$. \\
\hline & 0.008 & 0.015 & 0.03 & $\leqslant 0.06$ & $0 \cdot 125$ & 0.25 & 0.5 & 1.0 \\
\hline No. & NT & NT & NT & 194 & 39 & 39 & 5 & NT \\
\hline Per cent. & & & & $70 \cdot 0$ & $14 \cdot 1$ & $14 \cdot 1$ & $1 \cdot 8$ & \\
\hline
\end{tabular}

NT $=$ Not tested

TABLE IX Sensitivity of 277 strains of N. gonorrhoeae to cotrimoxazole and tetracycline in vitro

\begin{tabular}{|c|c|c|c|c|c|c|}
\hline \multirow{3}{*}{ Antibiotic } & \multicolumn{6}{|c|}{ Sensitivity } \\
\hline & \multicolumn{2}{|c|}{ Resistant } & \multicolumn{2}{|c|}{ Moderately sensitive } & \multicolumn{2}{|c|}{ Sensitive } \\
\hline & No. & Per cent. & No. & Per cent. & No. & Per cent. \\
\hline Cotrimoxazole & 11 & $4 \cdot 0$ & 66 & $23 \cdot 8$ & 200 & $72 \cdot 2$ \\
\hline Tetracycline & $\mathbf{0}$ & 0 & 0 & 0 & 277 & 100 \\
\hline
\end{tabular}


strains). This figure had increased to 32.9 per cent. (75 of 228 strains) in 1972 (Rodin and Seth, 1972). The present figure is 30 per cent. (83 of 277 strains), so that there does not appear to have been any change in the sensitivity pattern over the last 2 years.

The distribution of these less sensitive strains in the three treatment groups was approximately equal. If the sensitivities of strains in patients with recurrences are considered, $3 \mathrm{~g}$. ampicillin with probenecid appears to have a slightly better effect than $2 \mathrm{~g}$. ampicillin with probenecid although the figures are not statistically significant. It is possible that the extra $1 \mathrm{~g}$. ampicillin gives a slight degree of 'overkill'.

As the clinical results with ampicillin were as good as those with penicillin, we now use $3 \mathrm{~g}$. oral ampicillin with $2 \mathrm{~g}$. probenecid as the routine treatment for gonorrhoea at The London Hospital.

\section{Summary}

396 male patients with gonococcal urethritis were treated by one of three treatment schedules.

Of 132 patients treated with 2.4 m.u. procaine penicillin plus $2 \mathrm{~g}$. probenecid, 109 were followed. There were three $(2 \cdot 8$ per cent.) recurrences in the first week and none in the second.

Of 132 patients treated with $2 \mathrm{~g}$. ampicillin plus $2 \mathrm{~g}$. probenecid, 112 were followed. There were four (3.6 per cent.) recurrences in the first week and three ( 2.6 per cent.) in the second (total of 6.2 per cent.).

Of 132 patients treated with $3 \mathrm{~g}$. ampicillin plus $2 \mathrm{~g}$. probenecid, 115 were followed. There was one $(0.8$ per cent.) recurrence in the first week and five ( 4.4 per cent.) in the second (total of 5.2 per cent.).

A close correlation was found between the sensitivities of gonococcal strains to ampicillin and to penicillin. The overall sensitivity pattern of $N$. gonorrhoeae to penicillin had not changed at The London Hospital since the last report in 1972, but there was further evidence of cross-resistance between penicillin and cotrimoxazole.
We are grateful to Dr. R. B. Rothenberg for statistical advice. We should also like to thank Dr. P. Rodin for his help in the preparation of this paper, Mr. G. W. Lavender for his cooperation, and $\mathrm{Mr}$. Goldsmith and his nursing staff who contributed so greatly to the smooth running of the trial.

\section{References}

Alergant, C. D. (1963) Brit. F. vener. Dis., 39, 225

Bro-Jørgensen, A., and Jensen, T. (1971) Ibid., 47, 443

Cobbold, R. J. C., ReEs, G. D., Parker, R. B., WOODCOCK, K. R., John, J., Latto, D., Redmond, A., and Willcox, R. R. (1973) Ibid., 49, 268

ERIKsson, G. (1970) Acta derm.-venereol. (Stockh.), 50, 451

(1971a) Ibid., 51, 305

- (1971b) Ibid., 51, 467

Groth, O., and HALIQvist, L. (1970) Brit. F. vener. Dis., 46, 21

Gundersen, T., ÖdegaArd, K., and Gjessing, H. C. (1969) Ibid., 45, 235

Jersild, T., and Svendsen, T. L. (1973) Ibid., 49, 271

Keys, T. F., Halverson, C. W., and Clarke, E. J. (1969) f. Amer. med. Ass., 210, 857

Kvale, P. A., Keys, T. F., Johnson, D. W., and Holmes, K. K. (1971) Ibid., 215, 1449

ÖDEGAARD, K. (1962) Brit. med. F., 1, 645

RoBInson, O. P. W. (1964) Brit. F. clin. Pract., 18, 593

Rodin, P., and SETH, A. D. (1972) Brit. F. vener. Dis., 48, 517

Roy, R. B., and LAIRD, S. M. (1974) Ibid., 50, 117

STOKES, E. J. (1968) 'Clinical Bacteriology', 3rd ed. Arnold, London

and WATERWORTh, P. M. (1972) Ass. clin. Pathologists Broadsheet 55 (Revised)

Wigrield, A. S., Sekion, J. B., and Rich, G. E. (1973) Brit. F. vener. Dis., 49, 277

WILlCox, R. R. (1964a) Ibid., 40, 261

- (1964b) Postgrad. med. F., 40, Suppl. (Dec.), p. 202 (1965) Brit. F. clin. Pract., 19, 689

-, Woodcock, K. R., LATTO, D., JohN, J., REDMond, A., PARKer, R. B., Rees, G. D., and Cobbold, R. J. C. (1973) Brit. F. vener. Dis., 49, 263 